\title{
Typologies and Meanings of Prayer Among Patients
}

\section{Robert Klitzman ${ }^{1}$ iD}

Accepted: 23 February 2021

(c) The Author(s), under exclusive licence to Springer Science+Business Media, LLC, part of Springer Nature 2021

\begin{abstract}
Religion often aids patients, but critical questions arise concerning how patients approach issues regarding prayer. In-depth interviews suggest 12 key patient decisions and aspects of prayer-who prays, to whom (e.g., explicitly to "God" or not), for whom (for self or others), for what (e.g., for symptom reduction), when (regularly or only during crisis), where, what to say (pre-specified language or spontaneous), how consciously planned or not, with what expectations and outcomes, what to call it, and in what social contexts (e.g., how others view one's prayers). These data have implications for future research, clinical practice of physicians, nurses, chaplains, and other allied healthcare providers, and patient education.
\end{abstract}

Keywords Religion $\cdot$ Spirituality $\cdot$ Coping $\cdot$ Stress $\cdot$ Psychology

\section{Background}

Prayer is important to countless patients, but many questions arise concerning how they pray and make decisions about doing so. Medically ill older adults pray more than others (Koenig et al., 1998) and prayer has been found to be associated with spiritual well-being, faith and assurance (Levine et al., 2009) yet it is often misunderstood by providers. For instance, at the end of life, $89 \%$ of patients thought that praying was very important, though only $58 \%$ of providers did $(p<.001)$ (Steinhauser et al., 2000).

Several individual studies have examined aspects of prayer among various groups of patients, but have tended to assess different aspects of prayers, dividing these into relatively small numbers of categories (Ai et al., 2008; Gall \& Cornblat, 2002; Levine et al., 2009). Jors et al. (2015), for example, found that patients engage mostly in disease-centered prayer, but also assurance-centered, God-centered, and

Robert Klitzman

rlk2@cumc.columbia.edu

1 Vagelos College of Physicians and Surgeons, Joseph L. Mailman School of Public Health, Columbia University, 1051 Riverside Drive; Mail Unit \#15, New York, NY 10032, USA 
others-centered prayer and, more rarely, lamentations. Patients pray for healing, but also to positively transform the experience of their disease-to appreciate life and put their disease into a larger cosmological context (Jors et al., 2015). Other investigators have divided prayer into differing sets of categories, such as praying for others, conversational, petitionary, ritual and thanksgiving prayer (Smith et al., 2012). Meraviglia (2002) constructed three subscales among 32 adults with cancer-concerning prayer activities, prayer experiences and attitudes toward prayer-that were correlated with education, functional status, metastases, physical health, relationship to God and frequency of prayer. Ai et al. (2008) found that optimism was associated with prayer, but not with five specific types of prayer assessed-conversations with God, meeting spiritual or material needs, experiencing the Divine, memorized prayer or other types. In a qualitative study, 30 patients with cancer (Taylor et al., 1999) expressed themes of hesitancy about praying for particular things, conflicts about whether God was in control, questions regarding the reasons God allowed bad things to happen and the nature of God, bargaining with God, doubts about the efficacy of prayer, personal spirituality, value, worth and praying the right way. Yet many studies have examined primarily Christian patients (Jors et al., 2015), and questions arise regarding the range of phenomena that may exist within each of these categories in these varied studies, and ways the differing phenomena explored by these investigators might interrelate.

Research among healthy populations, rather than patients, has examined varying characteristics of prayer in general, also describing and categorizing it in differing ways, and doing so largely among healthy young college undergraduates. Ladd and Spilka (2006), for instance, conceptualized prayer as a way to establish three kinds of cognitive connections - inwardly, outwardly (to other people) and upwardly (toward God) — that comprise, in turn, eight scales: intercession, suffering, personal examinations, rest (e.g., stillness), sacrament, tears, radical (e.g., boldness) and petition. Paloma and Pendleton (1989) divided prayers into four types-meditative, ritualistic, petitionary and colloquial-that each relate differently to five quality-of-life measures (life and religious satisfaction, existential well-being, happiness and negative affect). Laird et al. (2009) split prayer into five types-adoration, thanksgiving, reception, confession and supplication. Whittington and Scher (2010) used these five prayer types and added a sixth - obligatory prayer-and found that the first three of these were correlated with well-being and focused more on God than on ego, while obligation and confession were correlated with negative indices. Perez et al. (2011) used Laird et al.'s (2009) seven categories and added three additional ones-prayers for one's health, emotional strength and others' well-being - and found that prayer for others was associated with thanksgiving prayer and inversely associated with depressive symptoms.

Yet the fact that the research on which these scales are based was conducted mostly on undergraduates raises vital questions regarding whether and to what degree these or other issues emerge among patients encountering significant illness, including death and dying, and who are often primarily older. Many questions thus remain regarding prayer among patients, and how to make sense of the wide heterogeneity of aspects of prayer probed thus far. 
In analyzing types of prayer among patients with different sets of diagnoses who participated in in-depth interview studies over several years (Klitzman, 1997, 2008, 2012, 2019), several cross-cutting themes and a larger framework emerged that can help make sense of the wide diversity reported in the literature thus far. This paper thus presents this framework.

\section{Methods}

This article draws on several recent in-depth qualitative research studies (Klitzman, 1997, 2008, 2012, 2019), regarding HIV, genetics testing, infertility and other conditions, in which these issues have often arisen, supplemented by other conversations with patients and providers. Methodological and other data from these studies have been reported elsewhere (Klitzman, 1997, 2008, 2012, 2019), focusing on other topics.

In brief, as reported elsewhere, these studies were designed to explore participants' views, experiences, challenges and decisions concerning the medical issues they confronted, including ways of coping and whether they faced religious or spiritual issues, to obtain "thick descriptions" (Geertz 1973). The Columbia University Department of Psychiatry Institutional Review Board approved the studies. Participants were recruited largely through flyers, websites, Listservs, e-mail and word of mouth. All participants volunteered to be part of the study and provided informed consent.

In each study, interviews were conducted until saturation for major and minor themes was reached. Interviews were all audiotaped, transcribed and content-analyzed, informed by grounded theory (Strauss \& Corbin, 1990), to identify categories of re-current themes and sub-themes. To ensure trustworthiness, these data were triangulated with existing literature. In these interviews, issues concerning prayer frequently arose spontaneously. The interviews were supplemented by participantobservation, drawing on other interactions with providers and patients, informed by ethnographic, qualitative research methods.

The current paper presents the themes that emerge concerning prayer, and includes representative quotes from the interviews, to also allow readers to judge these data for themselves. These data also have a certain face validity that, arguably, further substantiates their trust-worthiness.

These issues concerning prayers are brought together here for the first time and highlighted since they may contribute to, and inform the literature and future research and healthcare practice and education.

\section{Results}

As seen in Fig. 1, 12 key characteristics emerged regarding prayers, concerning, overall, their purpose, content, form and timing-specifically, who prays, to whom (whether to "God" per se, or not), for whom, for what (whether for disease or coping, and if the latter, for strength, reassurance and/or guidance), when (regularly and/ 


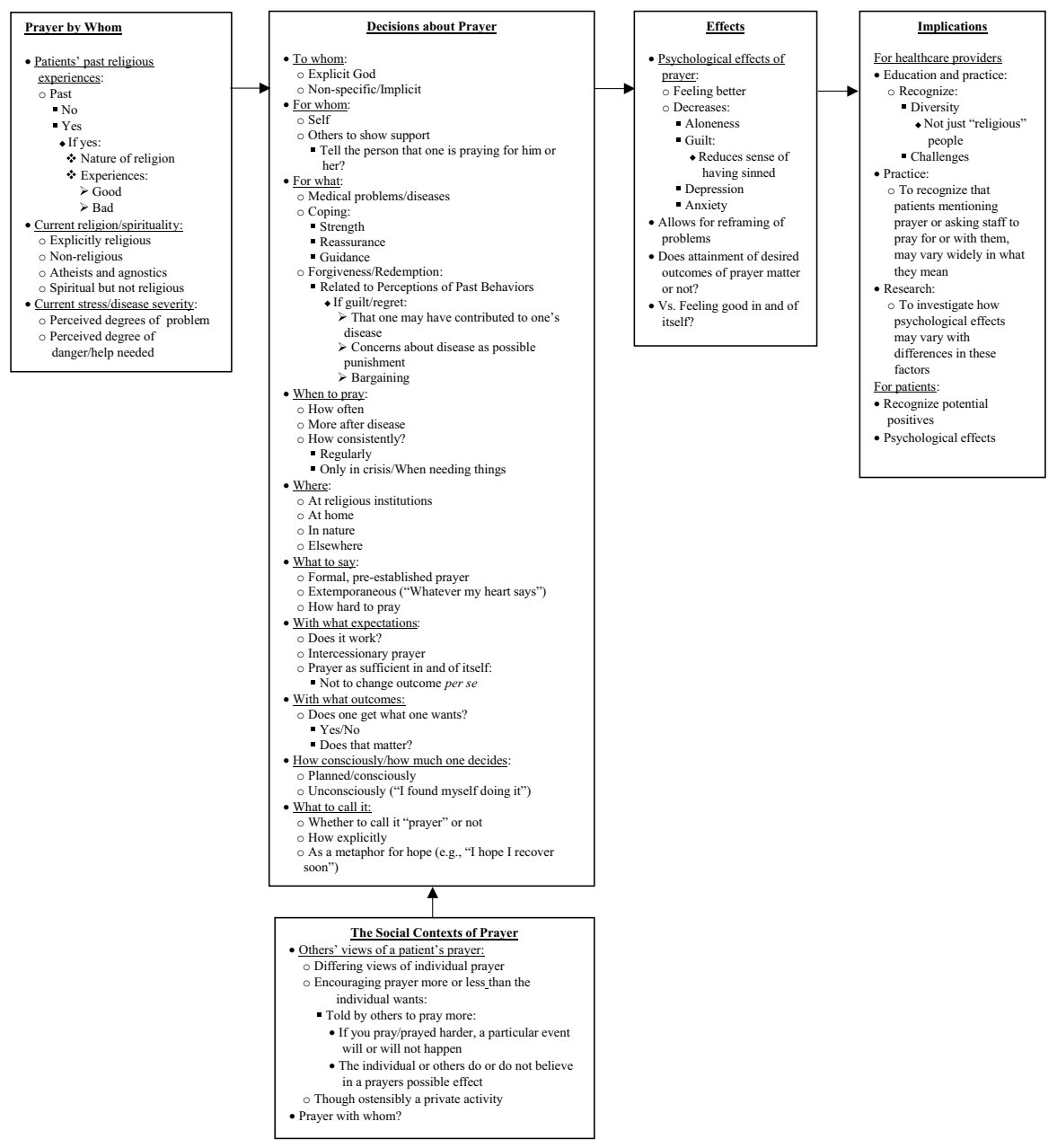

Fig. 1 Typologies of prayer

or at set times vs. only in crisis or when needing things), where (mostly at a religious institution vs. elsewhere), what to say (pre-specified, established language or spontaneous- "whatever my heart says"), how "consciously" planned or not (i.e., "finding myself doing it"), with what expectations, with what outcomes, what to call it (whether "prayer" or not), and in what social contexts. These aspects are often closely related to one another and cannot always be wholly separated-i.e., to whom one prays can potentially affect how one prays.

\section{Prayer by Whom: The Patient's Background}

While many patients who pray explicitly describe themselves as religious and firmly believe in God, others say they are atheist, agnostic or spiritual but not religious. 
Many patients have complex relationships with religion that can affect whether, how and for what they pray. Many atheists pray, even if unthinkingly. "I am not religious or spiritual. I'm a rationalist," a lawyer who had breast cancer, along with her sisters, told me. "I would never ask, Why me? I might, though, say it and fall on my knees and pray to a God I don't believe in, just because that's a natural reaction." Prayer can thus occur even among individuals who are atheist, or see themselves as "spiritual but not religious"-which they may interpret in a variety of ways.

Other patients may see themselves as members of a particular faith, but pick and choose in what behaviors, if any, to engage, and pray but not pursue other activities. As a 60-year-old woman who had breast cancer said, "I'm a traditionalist. I do the holidays, and very much believe in God, but am not religious. I believe in some spiritualism." Still, she's "proud of being Jewish... Whenever I'm in trouble, I pray. I think He has a path for everybody. I pray for my health, that we should all be well." After her husband "fell and hit his head, and had major brain surgery," she:

...prayed to God that he will be well. Given the world we live in today, I pray constantly-That the world is going to be good. I worry about my grandchildren growing up - that they'll be protected and ok. I pray before I go to bedthat I wake up in the morning! But I'm not a religious person-unfortunately. I should be, but I'm not. I do all the holidays with my children, but don't go to temple. I belonged to a temple for many years, and used to go. But I'm working, and getting older, so am happy to come home and stay in...My mother always said, 'You don't have to go to synagogue or temple. You can pray in the house,' so I pray a lot at home. I probably should go to temple, but unfortunately don't.

She suggests that she sees herself as "not religious," but not in the way that some members of the Jewish tradition use the term-as synonymous for "observant" (i.e., describing not the individual's general beliefs or attitudes about God, but very narrowly the degree of adherence to religious rules). Specifically, she does not even belong to a temple, because she prefers to stay home, suggesting that her not being religious is a matter of something broader and more fundamental than simply failing to adhere to certain particular religious rules such as keeping Kosher or observing the Sabbath. The fact that she nevertheless prays multiple times a day, underscores how "being religious" can refer to a range of behaviors and/or identities, and be open to some interpretation.

\section{Praying to Whom: Explicitly God or Not?}

Patients also differ in whether they pray specifically to "God" or not, and if so, how they conceive of Him. As a male endocrinologist with a chronic disease said,

I don't really know what to pray to. I'm not very religious. I was brought up Methodist. After traveling in India and the Far East, I like Buddhism. I find Hinduism interesting, but don't believe in all their multiplicity of Gods. I've come to feel that Christ, Buddha and Allah all actually represent the same 
horse. I pray to the Lord-you can call it God-for strength to get me through this, and wisdom to help me make the right decisions.

Yet he isn't actually consistently involved with any religious institution. While the woman above "pray(s) to God," this man wrestles with what to pray to, and doesn't accept a particular faith tradition's view, highlighting how the object of patients' prayers can differ.

\section{Praying for whom}

Patients also vary in whether they pray for themselves or others. Many patients ask close family, friends, providers and others to pray for them. A devout Jewish physician with skin cancer always wore a yarmulke and appeared to emanate a certain religious seriousness, earnestness and integrity that prompted many of his patients to ask him to pray for them. "Patients regard me as a little bit special because of the yarmulke. Even non-Jewish patients ask me to pray for them." At first, their requests surprised him, but he now always complies, reciting a Jewish prayer, regardless of the patient's faith. Many patients, regardless of their own religious backgrounds, seek his religious presence.

Patients may also want to have prayers from individuals whom they have met not only in person, but also online. "I'm part of an online group for Jewish religious women with special needs children," an Orthodox woman whose daughter was born with a severe congenital abnormality said. "We encourage, vent, and pray for each other. It's very inspiring."

\section{Praying for what}

Patients vary, too, in what they pray for. While some people pray simply to have the experience of communicating with the Divine, without asking for anything, patients facing serious illness often pray for psychological strength, solace, forgiveness, redemption and/or physical recovery from disease. In the face of obstacles, patients commonly seek courage and strength to persevere: "I don't ask God for anything except to give me strength to do what I have to do, or to keep my kids strong. When I pray, I'm only asking God to keep me from gaining an ego and false pride."

Regardless of their current religious affiliation, behavior or belief, many patients pray for health and happiness. A secretary at risk for Huntington's disease, since her father had the disease, explained, "I was raised Catholic but don't really believe a lot of it. It's too strict. But, I believe in God-that you should pray. I don't pray for money, or stuff we can't control. I don't say, 'Please let me get something.' I just pray for me and my family to be healthy and happy."

Others pray to seek answers or explanations regarding why they or a family member must confront serious medical problems. "What did I do to deserve this?" a 38-year-old infertile woman who had undergone multiple unsuccessful treatments, asked. 
Emotionally, there's a whole process-I wanted something, someone, some reason to blame. What brought this upon me? I was definitely ticked off at God and thought: 'Just let it happen, it would be easier on both of us'...I prayed, begged, pleaded, tried not praying - the whole spectrum. Mostly I kept it all in perspective: Maybe my body was just not able to have a child. But I started thinking: 'Maybe it wasn't meant to happen. Maybe my body isn't meant to.'

Individuals who may have contributed to their disease in some way, such as through substance abuse or unsafe sex, commonly wrestle with guilt and regrets, and also seek pardon, mercy, solace or exoneration. The Serenity Prayer is central to Alcoholics Anonymous (which has been far more successful than psychotherapy or medication in treating addictions) and states: "God grant me the serenity to accept the things I cannot change; courage to change the things I can; and wisdom to know the difference."

Individuals grappling with addiction often struggle with whether their disease somehow constitutes punishment, and they may pray to seek pardon. A Vietnam veteran said that when he learned, while in prison, that he had HIV, which he assumes he acquired through unprotected sex with a woman, he:

...went to church and prayed and changed my life around. I said to God, 'You know I've killed people, and didn't mean it. I'm not a killer. Basically, I'm not a bad guy. I mean, I've done time in prison, but it certainly hasn't been because I've elected to be a criminal. I've been hurt, molested, abused, and raped... Now I've got the virus. But please don't let me die here.' And something clicked in my head: 'If I let you go out, you're gonna kill people.' So, I said, as if I were just talking to you now, 'Dear Lord, if you let me out, Lord, if you let me out, I'm not going to kill a soul.'

Here, he engages in bargaining as well, and increases prayer along with religiosity and religious behaviors-now going to church, and illustrating how illness can profoundly alter a person's prayer activity.

\section{When to Pray}

Patients also differ widely in when, and how often and regularly they pray. Some people do so at a set time, such as when going to bed or going to religious institutions, while others do so primarily when distressed. When I asked a gay man with HIV, for instance, if he prayed, he replied, "Not really. Just those times when I need to pray...when I'm having a rough time." A person's practice of prayer can thus fluctuate, not just in one direction, but back and forth over time, depending on life events.

People vary, too, in how often they pray, which can also shift over time, frequently increasing after illness. The mother of a three-year-old son with a congenital disease involving his heart and other organs said, 
I just have a very strong belief system. I'm Catholic. We pray a lot, which makes me just take every day as a blessed day. My son has brought so much love into my life. All his problems are nothing compared to the love he has brought me...A lot of people would see it as a punishment. But I don't. I just feel blessed to have him. Since I've had my son, I'm less controlling. I pray and meditate more.

Many individuals thus pray more often after they or a loved one becomes seriously ill. As she suggests, prayer can also entail or facilitate psychological reframing of problems (e.g., prayer "makes me just take every day as a blessed day"), putting these stresses in broader religious, spiritual, cosmological and existential perspectives.

Degrees of religious doubt can also affect how frequently patients pray, with many patients also feeling conflicted about whether and how often to do so. As a doctor with a chronic disease said,

Once in a while, I'll pray at night, and it makes me feel a little better. I don't know why I don't do it more often. Perhaps I should. I haven't been to church in years. I usually go when I'm home visiting my parents. It seems to make them happy. I feel the need to be more spiritual, and to access that part of my being, which has been dormant a long time. I would do better if I had it in my life more. I just have this darn skepticism... On the one hand, I want it and need it; on the other, I feel it's what weak, simple people rely on: a crutch.

Prayer makes him feel better, but he sees religion as something that weak individuals need; and he does not want to be "weak," "needy" or "dependent," and he thus prays less than he might otherwise. Spiritual and religious doubts can thus affect whether and how commonly one prays. The fact that he feels he should pray more, but does not do so, suggests how ambivalent patients can feel.

\section{Where to Pray}

Patients range, too, in where they pray-from doing so at home only, primarily at a religious institution, or in Nature. As the 60-year-old woman with breast cancer mentioned earlier reported, her mother told her she could pray at home, so does so, rather than at temple. She experiences a degree of conflict about whether to attend a religious institution, feeling some obligation to do so (saying she "unfortunately" doesn't go). But ultimately, she values more the convenience of staying home, revealing how individuals make tradeoffs about these issues.

Others also do not want to attend or belong to a religious institution, but nonetheless pray. As a gay medical student with HIV said, "I'm religious personally, but don't do anything with the community. Religion is supposed to be personal. It's between you and God or whomever you believe in. So, why do I need to go to the Church to have that personal relationship?" 


\section{What to say When Praying}

Patients range widely, too, in what they say when they pray-from formal, preestablished prayers to speaking "as if talking to a person." As an HIV-infected Bronx Latina woman who had never finished high school, said, "Now I pray every night. I say, 'God...' The first part I say in Spanish because that's the way I learned it when I was in church. I'll start as if I'm talking to a person. Sometimes, I ask Him to forgive me for being weak."

Similarly, many chaplains give "extemporaneous", rather than rote prayers, tailoring or adapting the prayers they provide to a particular patient, depending on his or her medical condition and personal beliefs and preferences. As one chaplain explained, "I may say, 'May Jane feel less pain and be surrounded by her loved ones. May the Higher Powers, who create and oversee all, help her.",

Many patients rely more on established prayers, though often choosing particular parts that may have special meaning to them. One HIV-infected gay man who moved to the USA from Mexico, for instance, feels his life is out of control, and he now prays for guidance.

I cry and am angry about life and say, 'Why?' We Catholics pray to Our Father. One part is very significant for me: Come to earth. Please, God, take control of things. Take me over. I feel alone, overwhelmed by life. Show me the way. Don't leave me alone. Take my life if you want, but show me how I should live it. Catholicism says that God created us and set us free, and that we later get punished based on whether we have behaved or not. But so many things are out of my control. I get overwhelmed and say, 'Don't let me be free. I can't control my life.'

\section{With What Expectations and Outcomes}

Patients differ, too, in their expectations of praying-whether they expect their prayers to be "heard" and/or "answered," and if so, to what degree they believe such a response is possible or subsequently occurs. Many people see prayer as simply psychologically helpful in and of itself, helping them feel better and diminishing feelings of depression, anxiety, guilt or aloneness. These benefits, even if due to a placebo effect and insufficient to directly cure disease itself, can nonetheless be helpful. A nurse with a Masters of Divinity degree said:

Whether or not there's a God, prayer benefits the person who prays. Prayer doesn't heal physically, but can certainly help heal the soul and spirit, and reduce feelings of isolation. The power to cure is totally different. I don't bank a lot on prayer for divine intervention. Miracles are rare-few and far between-as sporadic for the person who prays as for the person who doesn't. Still, prayer helps.

Others may wonder whether, or hope that, their prayers will somehow be "answered." As an endocrinologist with a chronic disease said, "the past few times, 
my prayer wasn't answered." Despite his skepticism, he nonetheless wonders if, and maintains hope that, they somehow might be.

Over time, as they confront additional medical problems, patients often struggle with these questions, and may come to pray not only for strength, but also to alter disease outcomes. A woman in her 40s, who had two sons die of a congenital disease, underwent genetic testing, seeking a cause, but didn't find one and remained perplexed.

Why would God allow this to happen-two children in a row? As Catholics, we believe that God doesn't make those decisions. We are free beings and make our own decisions. He's there more to give us strength and supportwhatever life brings to us. Other people may believe God does look down and make these decisions, and if you pray hard enough or live your life a certain way, He's going to decide whether your child lives or dies.

But these questions still plague her. Once she "got beyond" her "bitterness," she was able to say, “'Ok, God didn't do this to me,' or 'I don't fully grasp why it happened. I'm not going to understand. I just have to accept. But it's an ongoing battle. I haven't completely overcome it. It's a journey. It still creeps up on me, and I have to talk myself down from 'Why?',

She still wonders whether she could have avoided her children's disease if she had somehow prayed harder. Even now, she fluctuates.

Supporters of so-called intercessory prayer believe that having other people pray for a patient, in and of itself, even if the patient doesn't know about it, can directly alter biological disease processes in the patient's body beyond the placebo effect. Yet these claims have been controversial, with several studies failing to provide scientific support (de Aguiar et al., 2017). Nonetheless, as a Catholic gastroenterologist with abdominal cancer said: "Everyone sent me prayer cards and Mass cards. I was in everyone's prayers. It must have worked: I had more energy, which never diminished." She and many other patients believe that prayer can in fact directly affect the physical healing process, through God's intervention directly altering the disease process itself.

While many physicians are understandably wary of direct physiological effects of prayer, some appear more open to these possibilities, though to varying degrees. One physician, who himself had a heart attack, described a medical colleague who "came to believe in the 'power of prayer' to treat disease":

He did not become obsessive about it, but it meant a lot to him. He would just 'sit' with patients. In his retirement, he got a theology degree, and now gives talks on the power of prayer. Some doctors would not send him patients anymore. But he is incredibly attached to this idea. And I'm attached to him. There's no question: you certainly can call on things that you might not be able to describe, which make people feel better.

He and others who believe in these direct physiological effects of prayer are not always sure how exactly these processes operate. When I asked a physician who is also a rabbi how he thinks it works, he responded, "I don't know. It just 
does." He then paused and added, "Through God!" He required no additional explanation. Individuals who believe in these powers of prayer, even if they are physicians, thus do not necessarily feel the need to understand how these processes operate, but simply accept the intangible aspects involved.

Others feel that other people's prayers, when the patient knows about them, can help psychologically, if nothing else, by demonstrating support, but can potentially also directly affect healing itself. Patients can thus actively seek multiple effects of prayer simultaneously. A Jewish radiologist with melanoma, for instance, asked Jewish friends to pray for him, and he feels their efforts worked:

I called up five people that I consider very holy. They follow Jewish law, without fanfare or publicity. I figure they've got God on their side. I know it helped because, knowing they were doing it, I was functioning better...Prayer works! That's part of Jewish belief: you can change the way the world is going.

\section{How Much is Prayer Consciously Willed?}

Patients have also described praying without consciously planning to do so-almost unconsciously. As an endocrinologist with a chronic disease said, "I find myself praying - that this blood result will be good, that you're going to let this be good newswithout planning or thinking about it consciously..."

When struggling to cope with stress, prayer can appear as a natural, almost instinctual behavior. As an HIV-infected African-American woman said,

At the age of five, I remember knowing inside of me, without ever hearing it, that something made the trees and put the sun up there. I've had numerous spiritual awakenings throughout my life. I didn't know what they were, but they happened. I've prayed and felt that something put my body in a praying position.

Similarly, the atheist lawyer with breast cancer mentioned above said she might "fall on my knees and pray to a God I don't believe, in just because that's a natural reaction." Her intellectual and emotional reactions to stresses thus markedly differ.

Belief, and therefore prayer, cannot necessarily be willed. Patients may want to believe, and feel that praying is beneficial, even just psychologically, but find it difficult to do so. A social worker who had breast cancer and the mutation for it reported,

I'm almost envious: I've seen people have tremendous strength from believing in God, praying, worshipping, and going to church or temple-having something you can focus on, and really feeling there is a Greater Being that can make it all ok. I don't have that. I wish I did. The first time I ever wished I were religious was when I had cancer. I'm Jewish, but was not brought up in a religious household. Jewish identity was always important to me, but not in terms of the religiongoing to temple, believing in a God, or praying. I guess I'm too skeptical, for whatever reason.

She would like to feel strength from praying and religion, but finds it too hard to bring herself to do so. 


\section{What to Call it}

Individuals differ, too, in how they define and label "prayer." Even chaplains, for instance, may offer patients not "prayers," but "blessings," "good wishes," or "good thoughts." As one chaplain, said,

When patients tell me they're atheists, I just say, 'That's ok. We are happy to talk with everyone.' I always carry around little prayers from different faiths, but basically say the same thing to everyone: 'You have a choice. I can say a prayer for you, or give you good wishes'...I essentially end up saying the same thing to everyone: God give us strength. Give the surgeon the skill, strength and good judgement he needs'...Patients are almost always grateful.

Some patients decline her offer of "a prayer," but accept "good blessings," which they are then glad to receive. When she introduces herself to patients as a chaplain, some patients say they don't want to see her. She said, for example:

An older gentleman was lying in bed, staring at the ceiling. 'No, thank you,' he said. 'We don't need you.' But his wife said to him, 'Come on. Why not? What's the harm?' He reluctantly agreed. I moved to his bedside, and said, 'I give you good wishes: 'Oh God, please give the anesthesiologist, surgeon and recovery room nurses the guidance, good skill and judgement today. Especially if they face difficult issues, give them all the skill and good judgment You can so that they help this man get better. We hope that he gets the best care, which he deserves. Let today be a new beginning for him, filled with hope and joy.' He grabbed my hand. 'YES, Sister! I was just thinking about that this morning. Thank you for coming today!' He looked me in the eye and said, 'THANK YOU. YES!! YES!! God Bless you.'

Other patients and family members use the term "pray" to refer to far more informal activity (e.g., "I pray that my sister will feel better"), suggesting how the word may at times be employed almost metaphorically.

\section{In What Social Contexts}

Though ostensibly a private activity, social contexts frequently affect prayer. Family members, friends, healthcare providers and others may or may not support, agree with, or approve of, a patient's approaches to prayer, whatever these may be, and may think the individual should instead pray more, less and/or differently. These external others may insist, for instance, that if the individual prayed harder, a particular event would or would not occur. Patients may thus clash in their views of the needs for, and possible effects of, prayer. A nurse, for instance, said about her breast cancer risks:

My sister said that her cancer is 'God's will.' If cancer is part of God's plan for her, He is not punishing her. She thinks God spared me from it because I prayed. I don't believe that... Many people say, 'So-and-so was in a car wreck, 
but God spared them.' But is that the same God who makes bad things happen?

Healthcare providers can also interface with patients' decisions and approaches concerning prayer in several ways. Providers vary in whether and to what degree they support or ignore patients' prayers. As a healthcare provider who worked at a hospital said,

My son was in an accident and was Code Blue. I was outside the hospital room, praying. His doctor walked out and told me, 'What you are doing out here is as important as what we're doing in there.' Eventually, my son came back. I'll never forget that doctor saying that to me. That one line was the most important thing anyone has ever said to me...Thank God, in the end, my son did ok. I wanted to thank that doctor, and tell him how much I love him for saying that, but I never have. I occasionally see him around, but would feel too awkward saying something.

Patients can thus very much welcome, and feel deeply gratified by, such support from doctors. She also suggests how patients may see discussion of these topics with a physician as taboo.

Occasionally, patients ask providers to pray with them, often leaving these clinicians uncertain how to respond. Frequently, physicians are unprepared to respond to these requests, creating awkward encounters. As an anesthesiologist said,

I once was wheeling a young child off for surgery and thought there was a good chance he would die in the operating room. The parents might never see the child again. They said, 'will you pray with us?' I wasn't sure what to do. I'm Jewish and they were Christian. I said, 'I'll leave you alone to pray together,' and left the room. I have always felt badly about that, unsure if I did the right thing. What do you think?

Yet often, doctors may agree to pray with patients, when asked, since it can be supportive. As one oncologist reported, "Patients sometimes ask me: 'Will you pray for me?" He describes himself as "a lapsed Catholic" and remains surprised and uncertain how to respond. "I say: 'Uhh...Ok...' I do worse things every day"- -giving patients potent chemotherapies in desperate attempts to help them, though these drugs can have terrible side effects.

\section{Discussion}

These data highlight 12 key aspects of prayer, several of which have received little, no, or inconsistent attention in prior studies, and which suggest a framework that can help make sense of some of the heterogeneity that previous studies have reported. Specifically, these 12 decisions and characteristics concern not only whether one prays, but who does, to whom, for whom, for what, when (how often and consistently), where, and with what words, how consciously, with what expectations, with what outcomes (and to what degree and for how long), what 
to call this activity, and in what social contexts. Patients differ, too, in how they make these decisions. Though prior studies have each tended to perceive prayer as a fixed, stable, constant and unitary practice in a person's life, and as a distinct and isolated phenomenon, the present data underscore the importance of viewing prayer instead as embedded in the particular social, medical, temporal, religious and spiritual contexts of individuals' lives, and as potentially shifting over timee.g., how illness can affect patients' prayers, which can thus change. Though prayer may be easier to examine as an isolated phenomenon, divorced from the complexities of the rest of people's lives, such an approach misses critical aspects and the complex inter-relationships between these realms. Social contexts, for instance, particularly how others view and engage in prayer, can strongly affect patients' decisions of how, when and how frequently to pray. These data highlight, too, how much patients can vary in these regards.

Many prior studies of prayers in general have also sampled only or primarily undergraduate students, and contained relatively little diversity in age, religion or ethnicity, including mostly Caucasian Christians. The generalizability of such results to others, especially older individuals of diverse beliefs (e.g., Jewish, Muslim, Hindu, atheist, agnostic or "spiritual but not religious") confronting serious disease and the prospect of possible imminent death, may thus be relatively limited.

The framework outlined here suggests, too, that the considerable heterogeneity among scales and categorizations used in previous studies, each of which focused on different aspects of prayer, may result from the fact that these investigations frequently mixed together and combined different aspects of prayer, not distinguishing among, and instead lumping together into a relatively small set of three to five categories, distinct elements (e.g., of what one prays for, for whom, to whom, how frequently, with what words and expectations), and have tended not to examine the interpersonal, temporal, social, as well as medical contexts of people's lives. Whether one "petitions" God, for example, may depend in part on whether other people are encouraging or discouraging one to do so, and to what degree the individual is experiencing particular stresses or crises at a given time. Several studies have only examined whether or not patients pray and for what, but not, for instance, how frequently or with what expectations, outcomes or social support concerning prayer-all of which can play vital roles. Some earlier categorizations of prayer have assessed, for example, what patients pray for, but not how, when, to whom, or with what variations over time. Though some studies have examined the relationship between prayer overall and a few sociodemographic characteristics, such as race/ethnicity, education, gender and/or religious tradition, (Balboni et al., 2011) many investigations have not done so. Most prior research has also not investigated whether and how the various aspects and subtypes of prayer that arise here may be related to health or other key factors.

Studies have tended, too, to examine only self-described prayer-which may be a relatively narrow, limited and restricted phenomenon-and exclude more extemporaneous and unconsciously-decided prayer. The present data suggest how prayer may at time be more implicit than explicit, in some ways almost instinctual, with non-religious individuals and even atheists praying as well, raising 
questions about the definitions of prayer itself. Research heretofore has not examined these issues, but should do so in the future.

These findings concerning the diversity of types of prayer may also reflect the fact that the broader American religious and spiritual landscape is changing. The prevalence of religiously unaffiliated Americans has been growing, from $16 \%$ in 2007 to $26 \%$ in 2019, while the number of Christians has been decreasing, from 78 to $65 \%$ during that time (Pew Research Center, 2019). These ongoing, larger societal changes make these data increasingly valuable.

\section{Implications for Clinical Practice and Education}

These data also underscore how prayer can assist patients psychologically, partly by helping them to reframe their experiences, enabling them to view severe stresses due to illness more positively, putting these into broader religious, spiritual, existential, cosmological or philosophical perspectives (e.g., prayer helping patients to see each day as "blessed" and/or view their illness in larger contexts). Psychological research has described, in other domains, a therapeutic technique of cognitive reframing (Robson \& Troutman-Jordan, 2014), based on the goal of helping patients to view their situations differently than they do, to alter perceptions of stresses they face from negative to positive, to improve well-being or change behavior. Much research on prayer has sought to categorize specific types of hopes expressed in prayers, but has not explored how the psychological processes involved might work. Prayer can benefit patients even if it does not change their medical situation per se. Future research should thus also investigate further how such reframing operateshow exactly patients reframe their experiences, when patients do so, when doing so aids them psychologically, to what degrees, and for how long, and whether more explicit awareness of it might be helpful.

While scholars have seen people's religion as consisting of the "three B's" of belief, behavior and belonging (i.e., affiliation with a religious organization) ( $\mathrm{Hu}$, 2018), the present data suggest, too, how multiple complexities are involved, and how further subdivisions can play key roles and should be considered. Prayer lies within the realm of "behavior," but is clearly influenced by belief and belonging, though in manifold ways, and can occur with or without belief or belonging. Moreover, within the realm of religious behavior, the present data highlight needs to examine, too, when, how often, for how long, in what ways, and with what expectations and outcomes individuals engage in such a behavior, and how and why they make these decisions. Similar questions arise regarding other behaviors as well that future research can also investigate.

These data have important implications for practice and education of physicians, nurses, chaplains, clergy and others, education of patients, and families. Patients may mention prayer, yet range widely in what they mean, in ways that clinicians or others may fail to grasp or appreciate. These data highlight the importance of listening and responding to patients' religious concerns, even by non-religious health care professionals. Providers' enhanced understandings of these variations can help them know and assist patients as much as possible. Patients may, for instance, feel that 
their prayers are "unanswered," and thus feel disappointed. Yet chaplains and other providers who speak to patients about these practices can assist patients in examining experiences and finding solace and comfort, acknowledging and supporting patients through varying types of prayer.

At times, patients ask a provider to pray for or with them, and these clinicians may feel awkward and uncertain how to proceed, and hence decline or disregard such requests. Yet patients who ask if their doctor will pray for them may implicitly be asking, "Do you really care about me? Are you committed to doing everything you can to help me?" Atheistic doctors should not tell religious patients, 'I will pray for you," if that is insincere. Patients and their families may detect the inauthenticity. Such doctors can, however, potentially tell patients, "I wish you a quick recovery," "I will send you good wishes," or "May your faith heal and give you courage"- essentially de facto prayers. Many of these statements may be akin to prayers, especially given questions of how we define "prayer." Recognition of these complexities, types and nuances of prayer can thus be critical.

\section{Implications for Research}

Future research should explore prayer not just in isolation, and through single crosssectional studies, as has heretofore largely been done, but also in various social and temporal contexts, longitudinally over time, and among diverse groups of patients, including individuals who are agnostic, atheistic or spiritual but not religiousespecially given the likelihood of cultural and religious differences between patients and their healthcare providers. Such studies should probe more fully what decisions these varied individuals make regarding whether, how, when, for what, and with what words and expectations to pray-and how other factors such as expectations and perceived outcomes of prayer may be involved. Though research on prayer among patients has focused on cancer and surgery, patients commonly pray when confronting a wide range of other situations-including chronic diseases (e.g., diabetes), mental health disorders, and pain from other conditions-which should be probed as well.

This research has a few potential limitations. These data were gathered from a relatively limited number of patients and providers, but future research can explore these factors further among larger samples of patients who differ in relevant characteristics (e.g., disease type, severity, treatability and prognosis).

\section{Conclusions}

These data thus suggest how patients face wide ranges of questions and decisions regarding prayer, which can be critical for clinicians and others to be aware of to know how best to assist patients confronting the challenges posed by various diseases. This analysis thus has critical implications for enhancing research, clincial 
practice of physicians, nurses, chaplains and other allied healthcare providers, and patient education.

Acknowledgements The author thanks Jiseop Kim and especially Patricia Contino for their assistance with the preparation of this manuscript.

Author Contribution The author is responsible for the study's conception and design, as well as material preparation, data collection and analysis. The first draft of the manuscript was written by Dr. Klitzman, who read and approved the final manuscript.

Funding This article draws on research that was supported by the National Institute Health (grant \# K08MH001420), the National Human Genome Research Institute (grant \#R01 HG02431), and the National Center for Research Resources (grant \#UL1 RR024156).

\section{Declaration}

Conflicts of interest The authors declare that they have no conflict of interest.

\section{References}

Ai, A., Tice, T., Huang, B., Rodgers, W., \& Bolling, S. F. (2008). Types of prayer, optimism, and wellbeing of middle aged and older patients undergoing open-heart surgery: Types of prayer, optimism, and well-being of middle-aged and older patients undergoing open-heart surgery. Mental Health, Religion \& Culture, 11(1), 131-150. https://doi.org/10.1080/13674670701324798

Balboni, M. J., Babar, A., Dillinger, J., Prigerson, H. D., VanderWeele, T. J., Balboni, T. A., et al. (2011). "It depends": Viewpoints of patients, physicians, and nurses on patient practitioner prayer in the setting of advanced cancer. Journal of Pain and Symptom Management, 41(5), 836-847. https://doi. org/10.1016/j.jpainsymman.2010.07.008

de Aguiar, P. R. D. C., Tatton-Ramos, T. P., \& Alminhana, L. O. (2017). Research on intercessory prayer: Theoretical and methodological considerations. Journal of Religion and Health, 56(6), 1930-1936. https://doi.org/10.1007/s10943-015-0172-9

Gall, T. L., \& Cornblat, M. W. (2002). Breast cancer survivors give voice: A qualitative analysis of spiritual factors in long-term adjustment. Psycho-Oncology, 11(6), 524-535. https://doi.org/10.1002/ pon.613

Geertz, C. (1993). The interpretation of cultures. Basic Books.

Hu, A. (2018). Evaluating survey items of Buddhism religiosity in China. International Journal of Public Opinion Research, 30(40), 675-691. https://doi.org/10.1093/ijpor/edx018

Jors, K., Büssing, A., Hvidt, N. C., \& Baumann, K. (2015). Personal prayer in patients dealing with chronic illness: A review of the research literature. Evidence-based Complementary and Alternative Medicine, 2015, 927973. https://doi.org/10.1155/2015/927973

Klitzman, R. (1997). Being positive: The lives of men and women with HIV. Ivan R. Dee.

Klitzman, R. (2008). When doctors become patients. Oxford University Press.

Klitzman, R. (2012). Am I my genes?: confronting fate and family secrets in the age of genetic testing. Oxford University Press.

Klitzman, R. (2019). Designing babies: How technology is changing the ways we create children. Oxford University Press.

Koenig, H. G., George, L. K., \& Peterson, B. L. (1998). Religiosity and remission of depression in medically ill older patients. The American Journal of Psychiatry, 155(4), 536-542. https://doi. org/10.1176/ajp.155.4.536

Ladd, K. L., \& Spilka, B. (2006). Inward, outward and upward: Scale reliability and validation. Journal of the Scientific Study of Religion, 45(2), 233-251. https://www.jstor.org/stable/3838315?seq=1.

Laird, S. P., Snyder, C. R., Rapoff, M. A., \& Green, S. (2009). Measuring private prayer: Development, validation, and clinical application of the multidimensional prayer inventory. The International 
Journal for the Psychology of Religion, 14(4), 251-272. https://doi.org/10.1207/s15327582ijpr14 04_2

Levine, E. G., Aviv, C., Yoo, G., Ewing, C., \& Au, A. (2009). The benefits of prayer on mood and well-being of breast cancer survivors. Supportive Care in Cancer, 17(3), 295-306. https://doi. org/10.1007/s0052000804825 Epub 2008 Jul 17.

Meraviglia, M. G. (2002). Prayer in people with cancer. Cancer Nursing, 25(4), 326-331. https://doi. org/10.1097/00002820-200208000-00010

Perez, J. E., Smith, A. R., Norris, R. L., Canenguez, K. M., Tracey, E. F., \& DeCristofaro, S. B. (2011). Types of prayer and depressive symptoms among cancer patients: The mediating role of rumination and social support. Journal of Behavioral Medicine, 34(6), 519-530. https://doi.org/10.1007/s1086 5011-93339

Pew Research Center. (2019, October 17). In U.S., decline of Christianity continues at rapid pace: An update on America's changing religious landscape. Retrieved 29 January 2021, from https://www. pewforum.org/2019/10/17/in-u-s-decline-of-christianity-continues-at-rapid-pace/

Poloma, M. M., \& Pendleton, B. F. (1989). Exploring types of prayer and quality of life: A research note. Review of Religious Research, 31(1), 46-53. https://doi.org/10.2307/3511023

Robson, J. P., Jr., \& Troutman-Jordan, M. (2014). A concept analysis of cognitive reframing. Journal of Theory Construction \& Testing, 18(2), 55-59.

Smith, A. R., DeSanto-Madeya, S., Tracey, E. F., DeCristofaro, S., Norris, R. L., \& Mukkamala, S. L. (2012). How women with advanced cancer pray: A report from two focus groups. Oncology Nursing Forum, 39(3), E310-E316. https://doi.org/10.1188/12.ONF.E310-E316

Steinhauser, K. E., Christakis, N. A., Clipp, E. C., McNeilly, M., McIntyre, L., \& Tulsky, J. A. (2000). Factors considered important at the end of life by patients, family, physicians, and other care providers. JAMA, 284(19), 24762482. https://doi.org/10.1001/jama.284.19.2476

Strauss, A., \& Corbin, J. (1990). Basics of qualitative research: Techniques and procedures for developing grounded theory (4th ed.). Sage Publications.

Taylor, E. J., Outlaw, F. H., Bernardo, T. R., \& Roy, A. (1999). Spiritual conflicts associated with praying about cancer. Psycho-Oncology, 8(5), 386-394. https://doi.org/10.1002/(sici)1099-1611(19990 9/10)8:5\%3c386::aidpon407\%3e3.0.co;2-c

Whittington, B. L., \& Scher, S. J. (2010). Prayer and subjective well-being: An examination of six different types of prayer. The International Journal for the Psychology of Religion, 20, 59-68. https://doi. org/10.1080/10508610903146316

Publisher's Note Springer Nature remains neutral with regard to jurisdictional claims in published maps and institutional affiliations. 